NBER WORKING PAPER SERIES

\title{
PITFALLS IN MEASURING EXCHANGE RATE MISALIGNMENT: THE YUAN AND OTHER CURRENCIES
}

\author{
Yin-Wong Cheung \\ Menzie D. Chinn \\ Eiji Fujii \\ Working Paper 14168 \\ http://www.nber.org/papers/w14168
NATIONAL BUREAU OF ECONOMIC RESEARCH
1050 Massachusetts Avenue
Cambridge, MA 02138
July 2008

We thank for useful comments Jeffrey Frankel, the discussant, Christoph Fischer, and participants at the workshop "Panel Methods and Open Economies", held at Goethe University Frankfurt, May 21, 2008, organized by Michael Binder and Heinz Herrmann. Kavan Kucko provided assistance in collecting data, and Hiro Ito provided additional data. Financial support of faculty research funds of the University of California at Santa Cruz, the University of Wisconsin, the Japan Center for Economic Research grant, and the Nomura Foundation for Social Science research grant is gratefully acknowledged. The views expressed are solely those of the authors, and do not necessarily reflect the views of the National Bureau of Economic Research.

NBER working papers are circulated for discussion and comment purposes. They have not been peerreviewed or been subject to the review by the NBER Board of Directors that accompanies official NBER publications.

(C) 2008 by Yin-Wong Cheung, Menzie D. Chinn, and Eiji Fujii. All rights reserved. Short sections of text, not to exceed two paragraphs, may be quoted without explicit permission provided that full credit, including $\odot$ notice, is given to the source. 
Pitfalls in Measuring Exchange Rate Misalignment: The Yuan and Other Currencies Yin-Wong Cheung, Menzie D. Chinn, and Eiji Fujii

NBER Working Paper No. 14168

July 2008

JEL No. F31,F41

\begin{abstract}
$\underline{\text { ABSTRACT }}$
We evaluate whether the Renminbi (RMB) is misaligned, relying upon conventional statistical methods of inference. A framework built around the relationship between relative price and relative output levels is used. We find that, once sampling uncertainty and serial correlation are accounted for, there is little statistical evidence that the RMB is undervalued, even though the point estimates usually indicate economically significant misalignment. The result is robust to various choices of country samples and sample periods, as well as to the inclusion of control variables. We then update the results using the latest vintage of the data to demonstrate how fragile the results are. We find that whatever misalignment we detected in our previous work disappears in this data set.
\end{abstract}

Yin-Wong Cheung

Department of Economics

University of California

Santa Cruz, CA 95064

cheung@ucsc.edu

Menzie D. Chinn

Dept. of Economics

University of Wisconsin

1180 Observatory Drive

Madison, WI 53706

and NBER

mchinn@lafollette.wisc.edu
Eiji Fujii

Graduate School of Systems

and Information Engineering

University of Tsukuba

Tennodai 1-1-1

Tsukuba, Ibaraki

Japan

efujii@sk.tsukuba.ac.jp 


\section{Introduction}

China's currency, the Renminbi (RMB), has occupied a central role in the ongoing debate over the source of global current account imbalances. In this paper, we step back from the debate over the merits of one exchange rate regime versus another and whether a currency realignment is desirable, and focus on the issue of currency misalignment in terms of economic theory and empirics. As in Cheung et al. (2007), we focus on the difficulty in measuring the "equilibrium real exchange rate" and on quantifying the uncertainty surrounding the measurement of the level of the equilibrium.

We exploit a well-known relationship between deviations from absolute purchasing power parity and real per capita income using panel regression methods. By placing the RMB in the context of this well-known empirical relationship exhibited by a large number of developing and developed countries, over a long time horizon, this approach addresses the question of where China's real exchange rate stands relative to the "equilibrium" level. In addition to calculating the numerical magnitude of the degree of misalignment, we assess the estimates in the context of statistical uncertainty. In this respect, we extend the standard practice of considering both economic and statistical significance in coefficient estimates to the prediction aspect.

We then update this basic set of results using the most recent vintage of available data, released in April 2008. This revision has been discussed extensively, as it incorporates substantial changes in estimates of price levels, and hence in income levels. We find that the estimated misalignment detected in our previous study disappears completely with this new data set. This finding highlights the fact that statistical uncertainty is something that needs to be taken seriously in policy debates.

We also extend the analysis by allowing for heterogeneity across country groupings and time periods. After conducting various robustness checks, we conclude that although the point estimates indicate the RMB is undervalued in almost all samples, in almost no case is the deviation statistically significant, and indeed, when serial correlation is accounted for, the extent of misalignment is not even statistically significant at the 50\% level. These findings highlight the great degree of uncertainty surrounding empirical estimates of "equilibrium real exchange rates", thereby underscoring the difficulty in accurately assessing the degree of RMB undervaluation. 
We further assess the robustness of the results in the presence of several conditioning variables. These additional factors include demographic variables, measures of trade openness, policy factors such as the extent of capital controls, and institutional factors. While these conditioning variables exert significant effects, their inclusion does not change the basic message: the RMB does not appear to be undervalued.

\section{Absolute Purchasing Power Parity}

At the heart of the debate over the right way of determining the appropriate exchange rate level are contrasting ideas of what constitutes an equilibrium exchange rate, what time frame the equilibrium condition pertains to, and, not least, what econometric method to implement. ${ }^{1}$ Some short cuts have been used so often that some forget that they are short cuts.

Most of the extant studies fall into some familiar categories, either relying upon some form of relative purchasing power parity (PPP) or cost competitiveness calculation, the modeling of deviations from absolute PPP, a composite model incorporating several channels of effects (sometimes called behavioral equilibrium exchange rate models), or flow equilibrium models. ${ }^{2}$ In Cheung et al. (2007), we review these alternative approaches.

In this study, we appeal to a simple, and apparently robust, relationship between the real exchange rate and per capita income. We will then elaborate the analysis by stratifying the data along other dimensions (level of development, time period), and by adding in other variables that might alter one's assessment of the fundamental equilibrium level of the exchange rate.

\subsection{The Real Exchange Rate - Income Relationship}

First, let us consider the basic framework of analysis. Consider the law of one price, which states that the price of a single good should be equalized in common currency terms (expressed in logs):

$1 \quad$ One relevant work is Hinkle and Montiel (1999).

2 See Table 1 of Cheung, Chinn and Fujii (forthcoming) for a typology of these different approaches. 


$$
p_{i, t}=s_{t}+p_{i, t}^{*}
$$

where $s_{t}$ is the $\log$ exchange rate, $p_{i, t}$ is the $\log$ price of good $i$ at time $t$, and the asterisk denotes the foreign country variable. Summing over all goods, and assuming the weights associated with each good are the same in both the home country and foreign country basket, one then obtains the absolute purchasing power parity condition:

$$
p_{t}=s_{t}+p_{t}^{*}
$$

where for simplicity assume $p$ is a arithmetic average of individual log prices. As is well known, if the weights differ between home and foreign country baskets (let's say production bundles), then even if the law of one price holds, absolute purchasing power parity need not hold.

The "price level" variable in the Penn World Tables (Summers and Heston, 1991), and other purchasing power parity exchange rates, attempt to circumvent this problem by using prices (not price indices) of goods, and calculating the aggregate price level using the same weights. Assume for the moment that this can be accomplished, but that some share of the basket $(\alpha)$ is nontradable (denoted by N subscript), and the remainder is tradable (denoted by $\mathrm{T}$ subscript). Then:

$$
p_{t}=\alpha p_{N, t}+(1-\alpha) p_{T, t}
$$

By simple manipulation, one finds that the "real exchange rate" is given by:

$$
q_{t} \equiv s_{t}-p_{t}+p_{t}^{*}=\left(s_{t}-p_{T, t}+p_{T, t}^{*}\right)-\alpha\left[p_{N, t}-p_{T, t}\right]+\alpha\left[p_{N, t}^{*}-p_{T, t}^{*}\right]
$$

Rewriting, and indicating the first term in (parentheses), the intercountry price of tradables, as $q_{T, t}$ and the intercountry relative price of nontradables as $\omega_{t} \equiv$ $\left[p_{N, t}-p_{T, t}\right]-\left[p_{N, t}^{*}-p_{T, t}^{*}\right]$, leads to the following rewriting of (4):

$$
q_{t}=q_{T, t}-\alpha \omega_{t}
$$

This expression indicates that the real exchange rate can appreciate as changes occur in the relative price of traded goods between countries, or as the relative price of nontradables rises in one country, relative to another. In principle, economic factors can affect one or both.

Most models of the real exchange rate can be categorized according to which specific relative price serves as the object of focus. If the relative price of nontradables is 
key, then the resulting models - in a small country context - have been termed "dependent economy" (Salter, 1959, and Swan, 1960) or "Scandinavian" model. In the former case, demand side factors drive shifts in the relative price of nontradables. In the latter, productivity levels and the nominal exchange rate determine the nominal wage rate, and hence the price level and the relative price of nontradables. In this latter context, the real exchange rate is a function of productivity (Krueger, 1983: 157). Consequently, the two sets of models both focus on the relative nontradables price, but differ in their focus on the source of shifts in this relative price. Since the home economy is small relative to the world economy (hence, one is working with a one-country model), the tradable price is pinned down by the rest-of-the-world supply of traded goods. Hence, the "real exchange rate" in this case is $\left(p^{N}-p^{T}\right)$.

By far dominant in this category are those that center on the relative price of nontradables. These include the specifications based on the approaches of Balassa (1964) and Samuelson (1964) that model the relative price of nontradables as a function of sectoral productivity differentials, including Hsieh (1982), Canzoneri, Cumby and Diba (1999), and Chinn (2000a). They also include those approaches that include demand side determinants of the relative price, such as that of DeGregorio and Wolf (1994). They observe that if consumption preferences are not homothetic and factors are not perfectly free to move intersectorally, changes in per capita income may result shifts in the relative price of nontradables.

This perspective provides the key rationale for the well-known positive crosssectional relationship between relative price (the inverse of $q$, i.e., $-q$ ) and relative $p e r$ capita income levels. We exploit this relationship to determine whether the Chinese currency is undervalued. Obviously, this approach is not novel; it has been implemented recently by Frankel (2006) and Coudert and Couharde (2005). However, we will expand this approach along several dimensions. First, we augment the approach by incorporating the time series dimension. ${ }^{3}$ Second, we explicitly characterize the uncertainty surrounding our determinations of currency misalignment. Third, we examine the

$3 \quad$ Coudert and Couharde (2005) implement the absolute PPP regression on a crosssection, while their panel estimation relies upon estimating the relationship between the relative price level to relative tradables to nontradables price indices. 
stability of the relative price and relative per capita income relationship using a) subsamples of certain country groups and time periods, and b) control variables.

Before proceeding further, it is important to be explicit about the type of equilibrium we are associating with our measure of the "normal" exchange rate level. Theoretically, the equilibrium exchange rate in the Balassa-Samuelson approach is the one that is consistent with both internal and external balances. In reality, however, internal and external balance is not guaranteed. Thus, the estimated exchange rate measure is properly interpreted as a long-run measure and is ill-suited (on its own) to analyzing short run phenomena. As a remedy, we include control variables that are relevant for (short-run) variations in internal and external balances in the subsequent analyses. ${ }^{4}$

\subsection{The Basic Bivariate Results: Using the 2006 Vintage Data}

We compile a large data set encompassing up to 160 countries over the 19752004 period. Most of the data are drawn from the World Bank's World Development Indicators (WDI). Because some data are missing, the panel is unbalanced. Appendix 1 gives a greater detail on the data used.

Extending Frankel's (2006) cross-section approach, we estimate the real exchange rate-income relationship using a pooled time-series cross-section (OLS) regression, where all variables are expressed in terms relative to the US;

$$
r_{i t}=\beta_{0}+\beta_{1} y_{i t}+u_{i t},
$$

where $r=-q$ is expressed in real terms relative to the US price level, $y$ is per capita income also relative to the US. ${ }^{5}$ The results are reported in the first two columns of Table 1 , for cases in which we measure relative per capita income in either USD exchange rates or PPP-based exchange rates.

One characteristic of estimating a pooled OLS regression is that it forces the intercept term to be the same across countries, and assumes that the error term is

\footnotetext{
$4 \quad$ Frankel (2006) discusses whether one can speak of an "equilibrium exchange rate" when there is more than one sector to consider.

$5 \quad \beta_{0}$ can take on currency specific values if a fixed effects specification is implemented. Similarly, the error term is composed of a currency specific and aggregate error if the pooled OLS specification is dropped.
} 
distributed identically over the entire sample. Because this is something that should be tested, rather than assumed, we also estimated random effects and fixed effects regressions. The former assumes that the individual specific error is uncorrelated with the right hand side variables, while the latter is efficient when this correlation is non-zero. ${ }^{6}$

Random effects regressions do not yield substantially different results from those obtained using pooled OLS. Interestingly, when allowing the within and between coefficients to differ, we do find differing effects. In particular, with US\$ based per capita GDP, the within effect is much stronger than the between. This divergence is likely picking up short term effects, where output growth is correlated with other variables pushing up currency values. This pattern, however, is not present in results derived from the PPP-based output data.

Interestingly, the estimated elasticity of the price level with respect to per capita income does not appear to be particularly sensitive to measurements of per capita income. In all cases, the elasticity estimate is always around $0.25-0.39$, which compares favorably with Frankel's (2006) 1990 and 2000 year cross-section estimates of 0.38 and 0.32 , respectively. ${ }^{7}$

One of the key emphases of our analysis is the central role accorded the quantification of the uncertainty surrounding the estimates. That is, in addition to estimating the economic magnitude of the implied misalignments, we also assess whether the implied misalignments are statistically different from zero. In Figure 1, we plot the actual and resulting predicted rates and standard error bands derived from the PPP-based data. The results pertaining to US\$ based per capita GDP data are qualitatively similar and, thus, are not reported for brevity.

It is interesting to consider the path that the RMB has traced out in the graph. It begins the sample as overvalued, and over the next three decades it moves toward the predicted equilibrium value and then overshoots, so that, by 2004, it is substantially

6 Since the price levels being used are comparable across countries, in principle there is no need to incorporate country-specific constants as in fixed effects or random effects regressions. In addition, fixed effects estimates are biased in the presence of serial correlation, which is documented in the subsequent analysis.

7 Note that, in addition to differences in the sample, our estimates differ from Frankel's in that we measure each country's (logged) real GDP per capita in terms relative to the US rather than in absolute terms. 
undervalued - by 53\% in level terms (greater in log terms). It is indeed a puzzle that the RMB path is different from the one predicted by the Balassa-Samuelson hypothesis. In comparing the observations at 1975 and 2004, we found that countries including Indonesia, Malaysia, and Singapore also experienced an increase in their income but a decrease in their real exchange rates. On the other hand, Japan - a country typically used to illustrate the Balassa-Samuelson effect, has a positive real exchange rate - income relationship. We reserve further analysis for future study.

In this context, we make two observations about these estimated misalignments. First, the RMB has been persistently undervalued by this criterion since the mid-1980s, even in 1997 and 1998, when China was lauded for its refusal to devalue its currency despite the threat to its competitive position.

Second, and perhaps most importantly, in 2004, the RMB was more than one standard error - but less than two standard errors - away from the predicted value, which in the present context is interpreted as the "equilibrium" value. In other words, by the standard statistical criterion that applied economists commonly appeal to, the RMB is not undervalued (as of 2004) in a statistically significant sense. The wide dispersion of observations in the scatter plots should give pause to those who would make strong statements regarding the exact degree of misalignment.

\subsection{Controlling for Serial Correlation}

Notice that the deviations from the conditional mean are persistent; that is, deviations from the real exchange rate - income relationship identified by the regression are persistent, or exhibit serial correlation. It has an important implication for interpreting the degree of uncertainty surrounding these measures of misalignment. Frankel (2006) makes a similar observation, noting that half of the deviation of the RMB from the 1990 conditional mean exists in 2000. We estimate the autoregressive coefficient in our sample at approximately 0.95 (derived from PPP-based per capita income figures) on an annual basis. A simple, ad hoc adjustment based upon the latter estimate suggests that the standard error of the regression should be adjusted upward by a factor equal to $[1 /(1-$ $\left.\left.\hat{\rho}^{2}\right)\right]^{0.5} \approx 2$. 
To provide a temporal dimension of the estimated misalignment, we trace the evolution of the RMB level over time, its predicted value, and the associated confidence bands adjusted to account for the serial correlation in Figure 2. The figure shows a striking feature - after controlling for serial correlation, the actual value of the RMB is always within one standard error prediction interval surrounding the (predicted) equilibrium value in the last 20 plus years! Combining this result and the large data dispersion observed in Figure 1, we have the impression that the data are not informative for a sharp misalignment inference - not just for the recent period but for the entire sample period.

While the ad hoc adjustment procedure offers a more accurate assessment of the degree of uncertainty surrounding the predicted level of misalignment, it gives no information on the estimated real exchange rate-relative income relationship that is free of serial correlation effects. In order to obtain estimates that are statistically correct in the presence of serial correlation, we implemented a panel version of the Prais-Winsten procedure. ${ }^{8}$ The results are reported in the third column of Table 1 .

The pooled OLS estimate using PPP-based per capita income indicates a short run elasticity of 0.15 , which is about one-half of the coefficient estimate without the serial correlation adjustment. The implied rate of adjustment is about 0.93 and the implied long-run elasticity is an implausibly high value of around 2. Relaxing the assumption that the errors are the same across time and individual countries (i.e., the random effects regression), we obtain a smaller short-run and hence long-run elasticity 0.13 and 1.8 , respectively. Since the Hausman tests rejects the orthogonality of the constant and the right hand side variable, we also consider the fixed effects regression

8 In essence, the Prais-Winsten method is an efficient procedure that incorporates serial correlation into the estimation process. We also implemented the Arellano-Bond approach that introduces lagged dependent variables into the model to account for serial correlation. The validity of the Arellano-Bond depends on the use of "good" instruments and the assumption that the number of time series observation is greater than the number of cross-sectional variables. In the current case, the choice of instruments is a practical issue and the time series dimension is smaller than the number of economies. In any case, the Arellano-Bond result is qualitatively similar to the one based on the ad hoc AR1 adjustment - the procedure gives a much larger standard error for a comparable estimate of undervaluation estimate given in Figure 1 These results are not presented for brevity. 
results. These indicate the cross-country elasticity as being 0.4 (that is the "between" effect), and the short run elasticity 0.04 (not significant).

Figure 3 shows the predicted RMB exchange rate based upon the pooled OLS estimates. Two observations are in order. First, for most of the sample period, the actual RMB value is within the one standard error prediction band - that is, the currency is insignificantly different from its predicted equilibrium value. The result is similar to the one depicted in Figure 2. Second, while the actual RMB value has been slightly below its predicted value since the 1997 Asian financial crisis year, the two values virtually have converged by 2004 and there is little indication of undervaluation. In fact, the 2004 actual value slightly exceeds the predicted one; suggesting an overvaluation of 0.2 percent albeit statistically insignificant. The surprising result is a consequence of taking serial correlation seriously - that is dealing with the high degree of persistence in the real exchange rate over time.

That being said, most of the time, the actual exchange rate is within about one standard error of the predicted, suggesting that the case for overvaluation is about as strong (or weak) as the case for undervaluation. ${ }^{9}$ In other words, we can have little certitude about RMB misalignment using this oft-used cross-country relationship between the real exchange rate and per capita income, once issues of serial correlation are explicitly accounted for.

It is well-known that serial correlation, if not appropriately corrected for, can lead to biased estimates and unreliable inferences. In the current exercise (illustrated in Figures 2 and 3), serial correlation is handled using two different approaches and yet yield similar inferences regarding RMB misalignment. Despite the apparent RMB undervaluation, both cases show that adjustment for serial correlation effects results in a much weaker case for a significantly undervalued RMB. In the next two sections, we shift our attention to other factors that might mediate the real exchange rate-relative income relationship.

\footnotetext{
${ }^{9}$ Frankel (2008) observes that the $5 \%$ significance level might be too stringent a criterion in this context. For instance, a 50\% significance level would be consistent with a plus/minus 0.67 standard error band.
} 


\subsection{The Basic Specification Updated: The 2008 Vintage Data}

We now repeat our basic analysis, using the 2008 vintage of data. Recently, the World Bank has reported new estimates of China's GDP and price level in 2005, measured in PPP terms. These estimates, based on the International Comparison Project's work, incorporated new benchmark data on prices. The end result was to reduce China's estimated GDP per capita by about $40 \%$, and increasing the estimated price level by the same amount. ${ }^{10}$ Using the previous vintage of data, and our previously estimated regression line, the RMB misalignment is eliminated.

However, taking proper account of this issue involves a slightly more involved approach. This is because data for many countries were substantially revised as well. This means that we need to re-estimate the regressions. We report these results in Table 2.

Focusing on the PPP based data, one finds that the pooled OLS results indicate a smaller impact of income on relative prices than obtained using the earlier data. The coefficient drops from 0.3 to 0.2 . In fixed effects regressions, the between coefficient drops while the within rises. Given the change in the sample period and the change in the estimated coefficients, one would not be too surprised to find the estimated misalignments change. However, the magnitude of the change in the implied misalignment for the RMB is surprising. Essentially, as of 2006, there is no significant misalignment, in either the economic or statistical sense. The undervaluation is on the order of $10 \%$ in log terms, and the maximal undervaluation is in 1993.

This outcome is clearly illustrated in Figures 4 and 5, where we present scatterplots of the price level against per capita income (using PPP and USD conversion rates, respectively), but utilizing the most recent data. These figures summarize our basic finding: namely that the substantial misalignment - on the order of $40 \%$ - detected in our previous analysis disappears in this analysis.

One might take this development as justification for our earlier conclusions that the statistical evidence for undervaluation was misplaced. However, our confidence bands were drawn based upon sampling uncertainty. The revision in China's position reflects measurement error, which we did not take into account in our previous analysis.

\footnotetext{
${ }^{10}$ Statistics from Asian Development Bank (2007). See also Elekdag and Lall (2008) and International Comparison Program (2007) for discussion.
} 
In Figures 6 and 7 we show the time series path for the RMB, against the predicted value, and the two standard error bands (not accounting for serial correlation ${ }^{11}$ ). It is clear from these graphs that there is no statistically significant misalignment.

\section{Analyses of Subsamples}

In the current and subsequent sections, we consider several variations of the basic bivariate structure in order to assess the robustness of our findings. To simplify presentation and conserve space, we focus on results pertaining to PPP-based output data and omit plots of the estimated misalignment profiles. In general, the results are quite robust to the choice of output data.

\subsection{Developed/Developing and Income Stratifications}

In Table 3, we report the results obtained from developed and developing countries. Interestingly, we find that the pooled OLS estimate is much larger for the developed countries than for the developing. This is somewhat surprising, given the widespread belief that Balassa-Samuelson effects are more pronounced in developing countries. Furthermore, the F-test indicates that the GDP effects are significantly different across the two country groups.

We investigate further by estimating random effects models. For developed countries, the GDP effect under the random effects model is slightly smaller than the one under the OLS setting; 0.55 versus 0.65 . The change in the case of developing countries is much more dramatic, and the random effects model gives a stronger GDP effect.

Using the developing country pooled OLS estimates, we find that the RMB is about $9.0 \%$ misaligned as of 2006 . The actual rate is again within two standard errors of the predicted.

When we break the sample into finer categories - namely into high, middle, and low income groupings - we find a pattern wherein the pooled OLS estimates are highest in the highest income group, and declines with income grouping (Table 4). A formal F-

\footnotetext{
${ }^{11}$ Note that the serial correlation in the residual drops only slightly in this data set, to about 0.94 .
} 
test confirms that the estimated GDP effects are significantly different across these income groups.

Moving to the fixed effects specifications (which appear to be appropriate for the middle and low income groupings) one finds that the elasticities are about the same, at $0.4,0.3$, and 0.5 for high, medium and low income groups. Table 4 also shows the between effects' estimate of the exchange rate-income elasticity of -0.18 for low income countries, while the within effect is about a half. In other words, for low income countries, there is substantial variation over time due to income changes.

Using the middle income country estimates, we estimate the extent of RMB undervaluation as close to $3.5 \%$ at 2006 .

\subsection{The East Asian Economies}

One question that stands out in our view is whether East Asia as a whole is distinguished from other countries in terms of its experience with real exchange rates. In addition, we have some a priori idea that Africa at the very least behaves in a different way than other developing countries. Hence, we also stratify the sample by regional grouping. The estimation results in Table 5 and the F-test statistics in its Notes section provide some evidence that there are indeed significant regional differences.

Asia and Latin America do not differ substantially in terms of the pooled OLS estimates, while Africa's coefficient is very much lower. The random effects specification is rejected by Hausman tests only in the case of Africa. Looking to the fixed effects regressions for Africa, we find the between coefficient is essentially zero, while the within coefficient is high. ${ }^{12}$ In sum, we conclude that it is important to differentiate between country groupings.

Using the Asia-specific coefficients, we find a $12.6 \%$ undervaluation for RMB, once again within the two standard error band.

\subsection{Different Sample Periods}

12 See Devereux (1999) for an early observation of this pattern. 
A third dimension along which to split the sample is along the time dimension. In particular, we use a break point of 1992/93, approximately halfway through the full sample.

The results reported in Table 6 are quite interesting. According to the OLS results, the slope coefficient is larger, by almost double, in the more recent period. ${ }^{13}$ However, this result does not stand up to allowing for random effects. Since the Hausman test rejects in both subsamples, we discuss the fixed effects estimates, which indicate the between effect has indeed been quite strong over the last thirteen years, while the within effect is lower relative to the earlier period. That is important, as we consider the fact that Chinese per capita income has been rising rapidly over time. These results suggest that the average per capita income is what is important in assessing under or overvaluation. Using the pooled OLS estimate results, we find the RMB is undervalued by $5.6 \%$.

Although our sample stratification scheme is not exhaustive, the results so far inspire the following general observation: the GDP effect in the real exchange raterelative income regression varies across country groups and across historical periods.

\section{Beyond the Bivariate Framework}

\subsection{Demographics, Policy, and Financial Development}

One remarkable feature of the previous results, using the newest vintage data, is the finding that the RMB is almost always undervalued by close $5-15 \%$ in log terms regardless of the sample used to make the assessment; moreover the null of no undervaluation cannot typically be rejected. These findings could be driven by the fact that the bivariate framework does not explicitly consider (short-run) internal and external imbalances which might be associated with certain variables. In this context, the serial correlation in the error term could signify the omission of serially correlated explanatory variables. Even though we can econometrically fix the serial correlation problem (see Section 2.3), it might be preferable to identify the relevant variables, in order to resolve

13 The slope coefficient estimates from year-by-year regressions show a similar upward trend. The slope coefficient starts with a low of 0.14 at 1975 and moves up gradually to the high of 0.39 at 1995 . Then it stays quite steady around the level of 0.36 for the rest of the sample. 
the problem in economic terms. These points suggest that one might want to broaden the set of determinants.

Once one moves away from a simple world where the per capita income differential is a proxy for Balassa-Samuelson effects, a whole universe of additional determinants suggest themselves. In particular, if the income variable proxies not only for productivity differentials, but also non-homotheticity of preferences, savings propensities, or impediments to the free flow of capital, then one would wish to include variables that pertain to these factors. Hence we augment the relative per capita income with demographics - under 14 and over 65 dependency ratios ${ }^{14}$ - and with an index of capital account openness developed by Chinn and Ito (2006). Finally, financial deepening is proxied by an M2/GDP ratio. ${ }^{15}$

The results are reported in the first column of Table 7. Interestingly, the elasticity of the price level with respect to relative income is drastically altered relative to the fullsample bivariate regression estimates (Table 2); at 0.023 , it is now close to zero. ${ }^{16}$ All the other variables show up as significant, save the population share over 65 .

Overall, the results suggest that capital account openness decreases the equilibrium value of the currency. Financial deepening also has a positive effect. This result does not appear to be the consequence of a spurious "credit boom" effect, since the "between" coefficient is more important than the "within" (or over time) coefficient.

Using pooled OLS on this specification implies an 8.6\% undervaluation in 2006 in $\log$ terms.

\subsection{Capital Account Openness and Institutions}

\footnotetext{
${ }^{14}$ See Rose and Supaat (2007) for a discussion. They focus on fertility rate, in their model of the trade weighted exchange rate, as their key demographic variable.

${ }^{15}$ In our previous analysis, we included a government deficit variable because Chinn and Prasad (2003) find that it explains part of current account balances over the medium term. In the newest version of the WDI, there were many missing observations; hence, we opted to exclude the fiscal variable, in order to maintain the sample size. Note that in our previous set of results, the budget deficit was seldom statistically significant.

${ }^{16}$ The results are also substantially different from the corresponding results obtained using the previous vintage of the WDI.
} 
One oft-heard argument is that the Chinese economy is special - namely it is one that is characterized by extreme corruption, as well as an extensive capital control regime. We investigate whether these two particular aspects are of measurable importance in the determination of exchange rates and, if so, whether our conclusions regarding RMB misalignment are altered as a consequence.

We augment the basic real exchange rate-relative income relationship with the aforementioned Chinn-Ito capital account openness index. In addition we use the International Country Risk Guide's (ICRG) Corruption Index as our measure of institutional development (where higher values of the index denote less corruption).

The results are reported in the right half of Table 7 . Since the corruption index is very slow moving, with a small time-varying component, it does not make too much sense to look at the fixed effects and random effects estimates. Focusing on the pooled estimates from PPP-based output data, one observes that the per capita income coefficient is largely in line with the previous estimates. Similarly, capital account openness enters in negatively. On the other hand, the (lack of) corruption enters in positively: The less corruption, the stronger the local currency.

We include an interaction term to allow for varying effects of capital openness in the presence of corruption. The estimates indicate that when capital account openness increases in absence of corruption, then the currency depreciates. This finding implies that when the capital account openness increases in the presence of relatively high levels of corruption, the equilibrium value of the currency is higher.

When we examine the time profile of the implied RMB undervaluation under the current model specification, we find that the standard error bands are wider, and the estimated degree of undervaluation commensurately smaller. In log terms, the undervaluation in 2006 is somewhat smaller than in the previous case, 3.3\%. In other words, to the extent that lack of transparency is given at an instant, the RMB is still not undervalued at conventional levels of statistical significance.

In sum, these control variables help explain a small portion of the estimated undervaluation reported in the previous section. However, when sampling uncertainty is taken into consideration, we still end up with the same inference: there is no strong and consistent statistical evidence of RMB misalignment in the recent sample period. Rather, 
the actual RMB value is in almost every case within the corresponding prediction interval. It is also noted that, despite the added variables, serial correlation is again found in specifications considered in Section 4.1 and 4.2.

\section{Some Concluding Thoughts}

While the empirical results thus far point to the difficulty in establishing the claim that RMB is significantly undervalued, it is imperative to recognize that these results $d o$ not constitute evidence of no undervaluation. Indeed, the statistical evidence is so "weak" that we cannot reject a wide range of hypotheses. For instance, we could not reject the null hypothesis that the RMB is $20 \%$ undervalued. In other words, the empirical relationship is very imprecisely estimated. That is, the empirical models and data are not sharp enough to allow a definite statistical conclusion.

In addition, the drastic changes in the estimated degrees of misalignment highlight the uncertainty that is attendant the data we use in these sorts of analyses. Unfortunately, it is harder to account for this type of uncertainty than it is for model uncertainty.

We should mention another shortcoming of our approach. Using our older data set, our bivariate estimation results identify 83 significant overvaluation cases and 78 significant undervaluation cases. Most of these instances correspond to extreme political and economic conditions. Interestingly, the real exchange rates of Thailand in 1996 and Argentina in 2001 are identified to be insignificantly (in a statistical sense) misaligned. ${ }^{17}$ The evidence is possibly indicative of the model's inability to reveal conditions before financial crises and the imprecision of the estimates.

This imprecision appears not to be unique to the current exercise, even though it is often overlooked. Dunaway, Leigh, and Li (2006) make a similar observation from a different perspective. These authors, using the RMB as an example, show that equilibrium real exchange rate estimates obtained from the various approaches and models commonly used in the literature exhibit substantial variations in response to small perturbations in model specifications, explanatory variable definitions, and time periods.

17 The bivariate estimation results indicate that a) the Thai baht was overvalued by $11.5 \%$ in 1996, and b) the Argentine peso was overvalued by 35\% in 2001. 
That is, inferences regarding misalignment are very sensitive to small changes in the way the equilibrium exchange rate is estimated.

To this conclusion, we add the finding that the results can be very sensitive to the data set used. The drastic change in our estimates of elasticities and implied misalignments associated with the mere switch in the vintage of a data starkly highlights this point. 


\section{References}

Asian Development Bank, 2007, Purchasing Power Parities and Real Expenditures (Manila, Philippines: Asian Development Bank, December).

Balassa, B. 1964, The Purchasing Power Parity Doctrine: A Reappraisal, Journal of Political Economy 72, 584-596.

Beck, T., Demirgüc-Kunt, A., Levine R., 2000, A new database on financial development and structure, Policy Research Paper No. 2147 (Washington, D.C.: World Bank).

Bosworth, B., 2004, Valuing the Renminbi, paper presented at the Tokyo Club Research Meeting, February 9-10.

Cairns, J., 2005, China: How Undervalued is the CNY?, IDEAglobal Economic Research (June 27).

Canzoneri, M., Cumby, R., Diba, B., 1996, Relative Labor Productivity and the Real Exchange Rate in the Long Run: Evidence for a Panel of OECD Countries, Journal of International Economics 47 (2), 245-66.

Cheung, Y., Chinn, M., Fujii, E., forthcoming, The Illusion of Precision and the Role of the Renminbi in Regional Integration, in Hamada, K., Reszat, B., Volz, U. (editors), Prospects for Monetary and Financial Integration in East Asia: Dreams and Dilemmas.

Cheung, Y., Chinn, M., Fujii, E., 2007, The Overvaluation of Renminbi Undervaluation, Journal of International Money and Finance 26(5) (September): 762-785.

Chinn, M., 2000a, The Usual Suspects? Productivity and Demand Shocks and AsiaPacific Real Exchange Rates, Review of International Economics 8 (1), 20-43.

Chinn, M.D., 2000b, Three Measures of East Asian Currency Overvaluation, Contemporary Economic Policy 18 (2), 205-214.

Chinn, M., Ito, H., 2006, What Matters for Financial Development? Capital Controls, Institutions and Interactions, Journal of Development Economics 61 (1), 163-192.

Chinn, M., Prasad, E., 2003, Medium-Term Determinants of Current Accounts in Industrial and Developing Countries: An Empirical Exploration, Journal of International Economics 59 (1), 47-76. 
Coudert, V., Couharde, C., 2005, Real Equilibrium Exchange Rate in China, CEPII Working Paper 2005-01 (Paris, January).

DeGregorio, J., Wolf, H.,1994, Terms of Trade, Productivity, and the Real Exchange Rate, NBER Working Paper \#4807 (July).

Devereux, M.B., 1999, Real Exchange Rates and Growth: A Model of East Asia, Review of International Economics 7, 509-521.

Dunaway, S., Leigh, L., Li, X., 2006, How Robust are Estimates of Equilibrium Real Exchange Rates: The Case of China, IMF Working Paper.

Dunaway, S., Li, X., 2005, Estimating China's Equilibrium Real Exchange Rate, IMF Working Paper .

Elekdag, Selim and Subir Lall, 2008, "International Statistical Comparison: Global Growth Estimates Trimmed After PPP Revisions," IMF Survey Magazine (Washington, D.C.: IMF, January 8).

Fernald, J., Edison, H., Loungani, P., 1999, Was China the First Domino? Assessing Links between China and Other Asian Economies, Journal of International Money and Finance 18 (4), 515-535.

Frankel, J., 2008, "Comment on Coine and Williamson, Equilibrium Exchange Rate of the Renminbi," in Goldstein, M. and Lardy, N. (editors), Debating China's Exchange Rate Policy (Washington, D.C.: Institute for International Economics, April), pp. 155-65.

Frankel, J., 2006, On the Yuan: The Choice between Adjustment under a Fixed Exchange Rate and Adjustment under a Flexible Rate, CESifo Economic Studies 52 (2), 246-75.

Funke, M., Rahn, J., 2005, Just how undervalued is the Chinese renminbi? World Economy 28, 465-89.

Goldstein, M., 2004, China and the Renminbi Exchange Rate, in Bergsten, C. F., Williamson, J. (editors), Dollar Adjustment: How Far? Against What? Special Report No. 17 (Washington, D.C.: Institute for International Economics, November).

Government Accountability Office, 2005, International Trade: Treasury Assessments Have Not Found Currency Manipulation, but Concerns about Exchange Rates 
Continue, Report to Congressional Committees GAO-05-351 (Washington, D.C.:

Government Accountability Office, April).

Hinkle, L.E., Montiel, P.J., 1999, Exchange Rate Misalignment (Oxford University Press/World Bank, New York).

Hsieh, D., 1982, The Determination of the Real Exchange Rate: The Productivity Approach, Journal of International Economics 12 (2), 355-362.

International Comparison Program, 2007, "Preliminary Results: Frequently Asked Questions," mimeo. http://siteresources.worldbank.org/ICPINT/Resources/backgrounder-FAQ.pdf Krueger, A.O., 1983, Exchange-Rate Determination (Cambridge, UK: Cambridge University Press).

Rogoff, K., 1996, The Purchasing Power Parity Puzzle, Journal of Economic Literature 34 (June), 647-668.

Prasad, E., Wei, S.-J., 2005, The Chinese Approach to Capital Inflows: Patterns and Possible Explanations, NBER Working Paper No. 11306 (April).

Rose, A. and Supaat, S., 2007, Fertility and the Real Exchange Rate, NBER Working Paper No. 13263 (July).

Salter, W.A., 1959, Internal and External Balance: The Role of Price and Expenditure Effects, Economic Record 35, 226-38.

Samuelson, P., 1964, Theoretical Notes on Trade Problems, Review of Economics and Statistics 46, 145-154.

Summers, R., Heston, A., 1991, The Penn World Table (Mark 5): An Expanded Set of International Comparisons, Quarterly Journal of Economics 106, 327-68.

Swan, T., 1960, Economic Control in a Dependent Economy, Economic Record 36, 5166.

Wang, T., 2004, Exchange Rate Dynamics, in Prasad, E. (editor), China's Growth and Integration into the World Economy, Occasional Paper No. 232 (Washington, D.C.: IMF), pp. 21-28.

Zhang, Z., 2001, Real Exchange Rate Misalignment in China: An Empirical Investigation, Journal of Comparative Economics 29, 80-94. 


\section{Appendix 1: Data and Sources}

The data for macroeconomic aggregates are drawn mostly from the World Bank's World Development Indicators. The old vintage is the 2006 version. The new vintage is the 2008 version. These include demographic variables, per capita income, M2/GDP and government deficits. The capital controls index is from Chinn and Ito (2006). The (inverse) corruption index is drawn from the International Country Risk Guide. Data for Taiwan are drawn from the Central Bank of China, International Centre for the Study of East Asian Development, and Asian Development Bank, Key Indicators of Developing Asian and Pacific Countries (old data set). 
Table 1: The panel estimation results of the real exchange rate - income relationship: 2006 vintage data

\begin{tabular}{|c|c|c|c|c|c|c|c|c|c|c|c|c|}
\hline & \multicolumn{4}{|c|}{ USD-based GDP } & \multicolumn{4}{|c|}{ PPP-based GDP } & \multicolumn{4}{|c|}{ PPP-based GDP (Prais-Winsten) } \\
\hline & $\begin{array}{l}\text { Pooled } \\
\text { OLS }\end{array}$ & Between & $\begin{array}{l}\text { Fixed } \\
\text { effects } \\
\text { (Within) }\end{array}$ & $\begin{array}{l}\text { Random } \\
\text { effects }\end{array}$ & $\begin{array}{l}\text { Pooled } \\
\text { OLS }\end{array}$ & Between & $\begin{array}{l}\text { Fixed } \\
\text { effects } \\
\text { (Within) }\end{array}$ & $\begin{array}{l}\text { Random } \\
\text { effects }\end{array}$ & $\begin{array}{l}\text { Pooled } \\
\text { OLS }\end{array}$ & Between & $\begin{array}{l}\text { Fixed } \\
\text { effects } \\
\text { (Within) }\end{array}$ & $\begin{array}{l}\text { Random } \\
\text { effects }\end{array}$ \\
\hline GDP per & $0.249 * *$ & $0.254 * *$ & $0.391 * *$ & $0.297 * *$ & $0.299 * *$ & $0.300 * *$ & $0.273 * *$ & $0.284 * *$ & $0.147 * *$ & $0.396 * *$ & 0.036 & $0.132 * *$ \\
\hline capita & $(0.003)$ & $(0.015)$ & $(0.029)$ & $(0.012)$ & $(0.006)$ & $(0.028)$ & $(0.031)$ & $(0.017)$ & $(0.021)$ & $(0.028)$ & $(0.025)$ & $(0.021)$ \\
\hline Constant & $\begin{array}{l}-.016 * * \\
(0.008)\end{array}$ & $\begin{array}{l}-.036 \\
(0.050)\end{array}$ & - & $\begin{array}{l}0.084 \\
(0.042)\end{array}$ & $\begin{array}{l}-.134 * * \\
(0.011)\end{array}$ & $\begin{array}{l}-.177 * * \\
(0.061)\end{array}$ & - & $\begin{array}{l}-.204 * * \\
(0.043)\end{array}$ & $\begin{array}{l}-.026 * * \\
(0.002)\end{array}$ & $\begin{array}{l}0.001 \\
(0.004)\end{array}$ & - & $\begin{array}{l}-.027 * * \\
(0.003)\end{array}$ \\
\hline Adjusted $\mathrm{R}^{2}$ & 0.496 & 0.617 & 0.763 & 0.496 & 0.349 & 0.413 & 0.754 & 0.349 & 0.012 & 0.389 & 0.021 & 0.012 \\
\hline $\begin{array}{l}\text { F-test } \\
\text { statistic }\end{array}$ & & & $29.468 * *$ & & & & $42.647 * *$ & & & & $1.218^{*}$ & \\
\hline $\begin{array}{l}\text { Hausman } \\
\text { test statistic }\end{array}$ & & & & $11.873 * *$ & & & & 0.167 & & & & $39.384 * *$ \\
\hline $\begin{array}{l}\text { Number of } \\
\text { observations }\end{array}$ & 4018 & & & & 4018 & & & & 3958 & & & \\
\hline
\end{tabular}

Notes: The data covers 160 countries over the maximum of a thirty-years period from 1975 to 2004 . The panel is unbalanced due to some missing observations. ${ }^{* *}$ and $*$ indicate $1 \%$ and $5 \%$ levels of significance, respectively. Heteroskedasticity-robust standard errors are given in parentheses underneath coefficient estimates. For the fixed effects models, the F-test statistics are reported for the null hypothesis of the equality of the constants across all countries in the sample. For the random effects models, the Hausman test statistics test for the independence between the timeinvariant country-specific effects and the regressor.

The third column labeled (Prais-Winsten) gives estimates from data with serial correlation removed using the Prais-Winsten method. The AR1 coefficient estimate for the Prais-Winsten transformation is 0.951. 
Table 2: The panel estimation results of the real exchange rate - income relationship: 2008 vintage data

\begin{tabular}{|c|c|c|c|c|c|c|c|c|c|c|c|c|}
\hline & \multicolumn{4}{|c|}{ USD-based GDP } & \multicolumn{4}{|c|}{ PPP-based GDP } & \multicolumn{4}{|c|}{ PPP-based GDP (Prais-Winsten) } \\
\hline & $\begin{array}{l}\text { Pooled } \\
\text { OLS }\end{array}$ & Between & $\begin{array}{l}\text { Fixed } \\
\text { effects }\end{array}$ & $\begin{array}{l}\text { Random } \\
\text { effects }\end{array}$ & $\begin{array}{l}\text { Pooled } \\
\text { OLS }\end{array}$ & Between & $\begin{array}{l}\text { Fixed } \\
\text { effects }\end{array}$ & $\begin{array}{l}\text { Random } \\
\text { effects }\end{array}$ & $\begin{array}{l}\text { Pooled } \\
\text { OLS }\end{array}$ & Between & $\begin{array}{l}\text { Fixed } \\
\text { effects }\end{array}$ & $\begin{array}{l}\text { Random } \\
\text { effects }\end{array}$ \\
\hline GDP per & $.211 * *$ & $.196 * *$ & $.552 * *$ & $.482 * *$ & $.194 * *$ & $.188 * *$ & $.415^{* *}$ & $.302 * *$ & $.188 * *$ & $.259 * *$ & $.147 * *$ & $.175 * *$ \\
\hline capita & $(.002)$ & $(.012)$ & $(.008)$ & $(.006)$ & $(.004)$ & $(.019)$ & $(.023)$ & $(.013)$ & $(.017)$ & $(.017)$ & $(.020)$ & $(.014)$ \\
\hline Constant & $\begin{array}{l}-.099 * * \\
(.008)\end{array}$ & $\begin{array}{l}-.157 * * \\
(.040)\end{array}$ & - & $\begin{array}{l}0.623 * * \\
(.026)\end{array}$ & $\begin{array}{l}-.276 * * \\
(.010)\end{array}$ & $\begin{array}{l}-.310 * * \\
(.045)\end{array}$ & - & $\begin{array}{l}-.078 * \\
(.035)\end{array}$ & $\begin{array}{l}-.020 * * \\
(.002)\end{array}$ & $\begin{array}{l}-.011 * * \\
(.002)\end{array}$ & & $\begin{array}{l}-.022 * * \\
(.003)\end{array}$ \\
\hline Adjusted $\mathrm{R}^{2}$ & .541 & .585 & .894 & .541 & .300 & .365 & .740 & .300 & .045 & .581 & .030 & .045 \\
\hline $\begin{array}{l}\text { F-test } \\
\text { Statistic }\end{array}$ & & & $82.484 * *$ & & & & $42.765 * *$ & & & & .632 & \\
\hline $\begin{array}{l}\text { Hausman } \\
\text { test statistic }\end{array}$ & & & & $112.50 * *$ & & & & $35.122 * *$ & & & & 3.650 \\
\hline $\begin{array}{l}\text { Number of } \\
\text { observations }\end{array}$ & 3946 & & & & 4031 & & & & 3933 & & & \\
\hline
\end{tabular}

Notes: The data covers 168 countries over the maximum of a twenty seven-years period from 1980 to 2006 . The panel is unbalanced due to some missing observations. ${ }^{*}$ and $*$ indicate $1 \%$ and $5 \%$ levels of significance, respectively. Heteroskedasticity-robust standard errors are given in parentheses underneath coefficient estimates. For the fixed effects models, the F-test statistics are reported for the null hypothesis of the equality of the constants across all countries in the sample. For the random effects models, the Hausman test statistics test for the independence between the time-invariant country-specific effects and the regressor.

The third column labeled (Prais-Winsten) gives estimates from data with serial correlation removed using the Prais-Winsten method. The AR1 coefficient estimate for the Prais-Winsten transformation is 0.943 . 
Table 3: The panel estimation results for developed versus developing country samples: 2008 vintage data

\begin{tabular}{|c|c|c|c|c|c|c|c|c|}
\hline & \multicolumn{4}{|c|}{ Developed countries } & \multicolumn{4}{|c|}{ Developing countries } \\
\hline & $\begin{array}{l}\text { Pooled } \\
\text { OLS }\end{array}$ & Between & $\begin{array}{l}\text { Fixed } \\
\text { effects } \\
\text { (Within) }\end{array}$ & $\begin{array}{l}\text { Random } \\
\text { effects }\end{array}$ & $\begin{array}{l}\text { Pooled } \\
\text { OLS }\end{array}$ & Between & $\begin{array}{l}\text { Fixed } \\
\text { effects } \\
\text { (Within) }\end{array}$ & $\begin{array}{l}\text { Random } \\
\text { effects }\end{array}$ \\
\hline GDP per capita & $\begin{array}{l}0.648^{* *} \\
(0.054)\end{array}$ & $\begin{array}{l}0.667 * * \\
(0.185)\end{array}$ & $\begin{array}{l}0.504 * * \\
(0.110)\end{array}$ & $\begin{array}{l}0.550 * \\
(0.094)\end{array}$ & $\begin{array}{l}0.108 * * \\
(0.005)\end{array}$ & $\begin{array}{l}0.095 * * \\
(0.020)\end{array}$ & $\begin{array}{l}0.428 * * \\
(0.025)\end{array}$ & $\begin{array}{l}0.254 * * \\
(0.014)\end{array}$ \\
\hline Constant & $\begin{array}{l}0.179 * * \\
(0.018)\end{array}$ & $\begin{array}{l}0.184 * * \\
(0.066)\end{array}$ & - & $\begin{array}{l}0.149 \\
(0.043)\end{array}$ & $\begin{array}{l}-.501 * * \\
(0.013)\end{array}$ & $\begin{array}{l}-.541 * * \\
(0.052)\end{array}$ & - & $\begin{array}{l}-.169 * * \\
(0.041)\end{array}$ \\
\hline $\begin{array}{l}\text { Adjusted } \mathrm{R}^{2} \\
\text { F-test } \\
\text { Statistic }\end{array}$ & 0.243 & 0.384 & $\begin{array}{l}0.550 \\
20.370^{* *}\end{array}$ & 0.243 & 0.113 & 0.148 & $\begin{array}{l}0.565 \\
27.229 * *\end{array}$ & 0.113 \\
\hline $\begin{array}{l}\text { Hausman } \\
\text { test statistic }\end{array}$ & & & & 0.606 & & & & $124.41 * *$ \\
\hline $\begin{array}{l}\text { Number of } \\
\text { observations }\end{array}$ & 540 & & & & 3024 & & & \\
\hline
\end{tabular}

Notes: The PPP-based real per capita income is used. The data covers 20 developed and 121 developing countries over the maximum of a thirty-years period from 1980 to 2006 . The panel is unbalanced due to some missing observations. ** and $*$ indicate $1 \%$ and $5 \%$ levels of significance, respectively. Heteroskedasticity-robust standard errors are given in parentheses underneath coefficient estimates. For the fixed effects models, the F-test statistics are reported for the null hypothesis of the equality of the constants across all countries in the sample. For the random effects models, the Hausman test statistics test for the independence between the time-invariant country-specific effects and the regressor. The F-test for the equality of the slope coefficients between the two samples gives a test statistic of 425.72 , which rejects the null hypothesis of equality. 
Table 4: The panel estimation results by income level stratifications: 2008 vintage data

\begin{tabular}{|c|c|c|c|c|c|c|c|c|c|c|c|c|}
\hline & \multicolumn{4}{|c|}{ High income countries } & \multicolumn{4}{|c|}{ Middle income countries } & \multicolumn{4}{|c|}{ Low income countries } \\
\hline & $\begin{array}{l}\text { Pooled } \\
\text { OLS }\end{array}$ & Between & $\begin{array}{l}\text { Fixed } \\
\text { effects } \\
\text { (within) }\end{array}$ & $\begin{array}{l}\text { Random } \\
\text { effects }\end{array}$ & $\begin{array}{l}\text { Pooled } \\
\text { OLS }\end{array}$ & Between & $\begin{array}{l}\text { Fixed } \\
\text { effects } \\
\text { (within) }\end{array}$ & $\begin{array}{l}\text { Random } \\
\text { effects }\end{array}$ & $\begin{array}{l}\text { Pooled } \\
\text { OLS }\end{array}$ & Between & $\begin{array}{l}\text { Fixed } \\
\text { effects } \\
\text { (within) }\end{array}$ & $\begin{array}{l}\text { Random } \\
\text { effects }\end{array}$ \\
\hline GDP per & $0.395 * *$ & $0.360 *$ & $0.414 * *$ & $0.408 * *$ & $0.115 * *$ & $0.080 * *$ & $0.331 * *$ & $0.274 * *$ & $-0.069 * *$ & $-0.177^{*}$ & $0.466 * *$ & $0.330 * *$ \\
\hline capita & $(0.047)$ & $(0.173)$ & $(0.057)$ & $(0.054)$ & $(0.013)$ & $(0.049)$ & $(0.035)$ & $(0.023)$ & $(0.018)$ & $(0.060)$ & $(0.036)$ & $(0.030)$ \\
\hline Constant & $\begin{array}{l}0.016 * * \\
(0.019)\end{array}$ & $\begin{array}{l}-0.005 \\
(0.070)\end{array}$ & - & $\begin{array}{l}0.010 \\
(0.043)\end{array}$ & $\begin{array}{l}-.538 * * \\
(0.023)\end{array}$ & $\begin{array}{l}-.614 * * \\
(0.090)\end{array}$ & - & $\begin{array}{l}-.275 * * \\
(0.048)\end{array}$ & $\begin{array}{l}-1.124 * * \\
(0.063)\end{array}$ & $\begin{array}{l}-1.511 * * \\
(0.204)\end{array}$ & - & $\begin{array}{l}0.195 \\
(0.106)\end{array}$ \\
\hline Adjusted $\mathrm{R}^{2}$ & 0.125 & 0.125 & 0.655 & 0.125 & 0.049 & 0.023 & 0.601 & 0.096 & 0.010 & 0.126 & 0.448 & 0.010 \\
\hline $\begin{array}{l}\text { F-test } \\
\text { statistic }\end{array}$ & & & $42.358 * *$ & & & & $35.375 * *$ & & & & $20.265^{* *}$ & \\
\hline $\begin{array}{l}\text { Hausman } \\
\text { test statistic }\end{array}$ & & & & 0.142 & & & & $4.433 *$ & & & & $43.591 * *$ \\
\hline $\begin{array}{l}\text { Number of } \\
\text { observations }\end{array}$ & 757 & & & & 1785 & & & & 1286 & & & \\
\hline
\end{tabular}

Notes: The PPP-based real per capita income is used. The data covers 29 high income countries, 73 middle income countries, and 54 low income countries over the maximum of a thirty year period from 1980 to 2006 . The panel is unbalanced due to some missing observations. ** and * indicate $1 \%$ and $5 \%$ levels of significance, respectively. Heteroskedasticity-robust standard errors are given in parentheses underneath coefficient estimates. For the fixed effects models, the F-test statistics are reported for the null hypothesis of the equality of the constants across all countries in the sample. For the random effects models, the Hausman test statistics test for the independence between the time-invariant country-specific effects and the regressor. The F-test for the equality of the slope coefficients between the samples based on the pooled OLS estimates gives test statistics of 247.141 for high income countries versus middle income countries, 182.664 for high income countries versus low income countries, and 45.970 for middle income countries versus low income countries. In all cases, the null hypothesis of equal slope coefficients is rejected at the conventional level of significance. 
Table 5: The panel estimation results by geographical stratifications: 2008 vintage data

\begin{tabular}{|c|c|c|c|c|c|c|c|c|c|c|c|c|}
\hline & \multicolumn{4}{|l|}{ Asia } & \multicolumn{4}{|c|}{ Latin America } & \multicolumn{4}{|l|}{ Africa } \\
\hline & $\begin{array}{l}\text { Pooled } \\
\text { OLS }\end{array}$ & Between & $\begin{array}{l}\text { Fixed } \\
\text { effects } \\
\text { (within) }\end{array}$ & $\begin{array}{l}\text { Random } \\
\text { effects }\end{array}$ & $\begin{array}{l}\text { Pooled } \\
\text { OLS }\end{array}$ & Between & $\begin{array}{l}\text { Fixed } \\
\text { effects } \\
\text { (within) }\end{array}$ & $\begin{array}{l}\text { Random } \\
\text { effects }\end{array}$ & $\begin{array}{l}\text { Pooled } \\
\text { OLS }\end{array}$ & Between & $\begin{array}{l}\text { Fixed } \\
\text { effects } \\
\text { (within) }\end{array}$ & $\begin{array}{l}\text { Random } \\
\text { effects }\end{array}$ \\
\hline $\begin{array}{l}\text { GDP per } \\
\text { capita }\end{array}$ & $\begin{array}{l}0.260 * * \\
(0.012)\end{array}$ & $\begin{array}{l}0.264 * * \\
(0.046)\end{array}$ & $\begin{array}{l}0.138 * \\
(0.066)\end{array}$ & $\begin{array}{l}0.216 * * \\
(0.034)\end{array}$ & $\begin{array}{l}0.396 * * \\
(0.020)\end{array}$ & $\begin{array}{l}0.405 * * \\
(0.055)\end{array}$ & $\begin{array}{l}0.327 * * \\
(0.058)\end{array}$ & $\begin{array}{l}0.359 * * \\
(0.034)\end{array}$ & $\begin{array}{l}0.049 * * \\
(0.009)\end{array}$ & $\begin{array}{l}0.018 \\
(0.038)\end{array}$ & $\begin{array}{l}0.589 * * \\
(0.033)\end{array}$ & $\begin{array}{l}0.367 * * \\
(0.026)\end{array}$ \\
\hline Constant & $\begin{array}{l}-0.122 * * \\
(0.024)\end{array}$ & $\begin{array}{l}-0.131 \\
(0.104)\end{array}$ & - & $\begin{array}{l}-.223 * * \\
(0.083)\end{array}$ & $\begin{array}{l}-.005 \\
(0.038)\end{array}$ & $\begin{array}{l}0.010 \\
(0.104)\end{array}$ & - & $\begin{array}{l}-.073 * \\
(0.068)\end{array}$ & $\begin{array}{l}-.626 * * \\
(0.030)\end{array}$ & $\begin{array}{l}-.729 * * \\
(0.127)\end{array}$ & - & $\begin{array}{l}0.380 * * \\
(0.090)\end{array}$ \\
\hline $\begin{array}{l}\text { Adjusted } \mathrm{R}^{2} \\
\text { F-test } \\
\text { statistic }\end{array}$ & 0.423 & 0.583 & $\begin{array}{l}0.690 \\
23.257 * *\end{array}$ & 0.423 & 0.405 & 0.659 & $\begin{array}{l}0.578 \\
12.127 * *\end{array}$ & 0.405 & 0.016 & -.018 & $\begin{array}{l}0.485 \\
24.504 * *\end{array}$ & 0.016 \\
\hline $\begin{array}{l}\text { Hausman } \\
\text { test statistic }\end{array}$ & & & & 1.881 & & & & 0.456 & & & & $\begin{array}{l}105.98 * \\
*\end{array}$ \\
\hline $\begin{array}{l}\text { Number of } \\
\text { observations }\end{array}$ & 569 & & & & 735 & & & & 1085 & & & \\
\hline
\end{tabular}

Notes: The PPP-based real per capita income is used. The data covers 23 Asian countries, 28 Latin American countries, and 43 African countries over the maximum of a thirty year period from 1980 to 2006 . The panels are unbalanced due to some missing observations. (The country classifications are as defined by the WDI. Asia does not include "South Asia", and Africa does not include "Middle East and North Africa".) ** and * indicate $1 \%$ and $5 \%$ levels of significance, respectively. Heteroskedasticity-robust standard errors are given in parentheses underneath coefficient estimates. For the fixed effects models, the F-test statistics are reported for the null hypothesis of the equality of the constants across all countries in the sample. For the random effects models, the Hausman test statistics test for the independence between the time-invariant country-specific effects and the regressor. The F-test for the equality of the slope coefficients between the samples based on the pooled OLS estimates gives test statistics of 49.810 for Asia versus Latin America, 113.241 for Latin America versus Africa, and 77.975 for Asia versus Africa. In only the latter case, the null hypothesis of equal slope coefficients is rejected at the conventional level of significance. 
Table 6: The panel estimation results for the 1980-1992 and 1993-2006 sub-samples: 2008 vintage data

\begin{tabular}{|c|c|c|c|c|c|c|c|c|}
\hline & \multicolumn{4}{|c|}{ 1980-1992 } & \multicolumn{4}{|c|}{$1993-2006$} \\
\hline & $\begin{array}{l}\text { Pooled } \\
\text { OLS }\end{array}$ & Between & $\begin{array}{l}\text { Fixed } \\
\text { effects } \\
\text { (Within) }\end{array}$ & $\begin{array}{l}\text { Random } \\
\text { effects }\end{array}$ & $\begin{array}{l}\text { Pooled } \\
\text { OLS }\end{array}$ & Between & $\begin{array}{l}\text { Fixed } \\
\text { effects } \\
\text { (Within) }\end{array}$ & $\begin{array}{l}\text { Random } \\
\text { effects }\end{array}$ \\
\hline GDP per & $0.128 * *$ & $0.117 * *$ & $0.565 * *$ & $0.236 * *$ & $0.237 * *$ & $0.233 * *$ & $0.402 * *$ & $0.281 * *$ \\
\hline capita & $(0.007)$ & $(0.024)$ & $(0.044)$ & (0.019) & $(0.005)$ & $(0.018)$ & $(0.037)$ & $(0.015)$ \\
\hline Constant & $\begin{array}{l}-.330 * * \\
(0.017)\end{array}$ & $\begin{array}{l}-.414 * * \\
(0.056)\end{array}$ & - & $\begin{array}{l}-.178 * \\
(0.046)\end{array}$ & $\begin{array}{l}-.245 * * \\
(0.014)\end{array}$ & $\begin{array}{l}-.253 * * \\
(0.044)\end{array}$ & - & $\begin{array}{l}-.153 * * \\
(0.039)\end{array}$ \\
\hline Adjusted $\mathrm{R}^{2}$ & 0.137 & 0.118 & 0.751 & 0.209 & 0.452 & 0.497 & 0.880 & 0.452 \\
\hline $\begin{array}{l}\text { F-test } \\
\text { statistic }\end{array}$ & & & $28.677 * *$ & & & & $50.187 * *$ & \\
\hline $\begin{array}{l}\text { Hausman } \\
\text { test statistic }\end{array}$ & & & & $66.375 * *$ & & & & $12.366 * *$ \\
\hline $\begin{array}{l}\text { Number of } \\
\text { observations }\end{array}$ & 1768 & & & & 2263 & & & \\
\hline
\end{tabular}

Notes: The PPP-based real per capita income is used. The data covers 159 countries over the 1980-1992 period, and 165 countries over the 1993-2006 period. The panels are unbalanced due to some missing observations. ${ }^{* *}$ and $*$ indicate $1 \%$ and $5 \%$ levels of significance, respectively. Heteroskedasticity-robust standard errors are given in parentheses underneath coefficient estimates. For the fixed effects models, the F-test statistics are reported for the null hypothesis of the equality of the constants across all countries in the sample. For the random effects models, the Hausman test statistics test for the independence between the time-invariant country-specific effects and the regressor. The F-test for the equality of the slope coefficients between the two sub-samples gives a test statistic of 136.705 , which rejects the null hypothesis of equality. 
Table 7: Estimation with control variables: 2008 vintage data

\begin{tabular}{|c|c|c|c|c|c|c|c|c|}
\hline & \multicolumn{4}{|c|}{$\begin{array}{l}\text { Demographics, policy, and financial } \\
\text { development }\end{array}$} & \multicolumn{4}{|c|}{ Capital account openness and corruption } \\
\hline & $\begin{array}{l}\text { Pooled } \\
\text { OLS }\end{array}$ & Between & $\begin{array}{l}\text { Fixed } \\
\text { effects } \\
\text { (Within) }\end{array}$ & $\begin{array}{l}\text { Random } \\
\text { effects }\end{array}$ & $\begin{array}{l}\text { Pooled } \\
\text { OLS }\end{array}$ & Between & $\begin{array}{l}\text { Fixed } \\
\text { effects } \\
\text { (Within) }\end{array}$ & $\begin{array}{l}\text { Random } \\
\text { effects }\end{array}$ \\
\hline GDP per & $0.023 * *$ & 0.016 & $0.519 * *$ & $0.272 * *$ & $0.149 * *$ & $0.110 * *$ & $0.337 * *$ & $0.239 * *$ \\
\hline capita & $(0.007)$ & $(0.027)$ & $(0.028)$ & $(0.017)$ & $(0.006)$ & $(0.026)$ & $(0.031)$ & $(0.015)$ \\
\hline Population & $0.973 * *$ & $1.151 * *$ & $-0.255 * *$ & $0.241 * *$ & & & & \\
\hline under 14 & $(0.050)$ & $(0.126)$ & $(0.061)$ & $(0.074)$ & & & & \\
\hline Population & -0.019 & -0.091 & 0.076 & $-0.168 * *$ & & & & \\
\hline over 65 & $(0.026)$ & $(0.068)$ & $(0.094)$ & $(0.052)$ & & & & \\
\hline Capital acct. & $-0.024 *$ & -0.065 & $0.052 * *$ & $0.037 * *$ & $-0.146^{* *}$ & $\begin{array}{l}-0.217 \\
(0.131)\end{array}$ & $0.061 *$ & 0.034 \\
\hline $\begin{array}{l}\text { openness } \\
\text { M2/GDP }\end{array}$ & $\begin{array}{l}0.0097 * * \\
(0.011)\end{array}$ & $\begin{array}{l}(0.046) \\
0.060 \\
(0.045)\end{array}$ & $\begin{array}{l}(0.012) \\
-0.128 * * \\
(0.029)\end{array}$ & $\begin{array}{l}(0.011) \\
-0.057 * * \\
(0.020)\end{array}$ & $(0.024)$ & $(0.131)$ & $(0.026)$ & $(0.024)$ \\
\hline Corruption & & & & & $\begin{array}{l}0.291 * * \\
(0.030)\end{array}$ & $\begin{array}{l}0.518 * * \\
(0.140)\end{array}$ & $\begin{array}{l}-0.044 \\
(0.025)\end{array}$ & $\begin{array}{l}-0.024 \\
(0.025)\end{array}$ \\
\hline $\begin{array}{l}\text { Interaction } \\
\text { term }\end{array}$ & & & & & $\begin{array}{l}0.335 * * \\
(0.036)\end{array}$ & $\begin{array}{l}0.454 * * \\
(0.174)\end{array}$ & $\begin{array}{l}0.023 \\
(0.030)\end{array}$ & $\begin{array}{l}0.061 * \\
(0.031)\end{array}$ \\
\hline Constant & $\begin{array}{l}-.811 * * \\
(0.024)\end{array}$ & $\begin{array}{l}-.861 * * \\
(0.095)\end{array}$ & & $\begin{array}{l}-.059 \\
(0.060)\end{array}$ & $\begin{array}{l}-.595^{* *} \\
(0.028)\end{array}$ & $\begin{array}{l}-.864 * * \\
(0.125)\end{array}$ & & $\begin{array}{l}-.219^{* *} \\
(0.041)\end{array}$ \\
\hline Adjusted $\mathrm{R}^{2}$ & 0.415 & 0.584 & 0.709 & 0.281 & 0.513 & 0.638 & 0.794 & 0.468 \\
\hline $\begin{array}{l}\text { F-test } \\
\text { statistic }\end{array}$ & & & $23.058 * *$ & & & & $28.289 * *$ & \\
\hline $\begin{array}{l}\text { Hausman } \\
\text { test statistic }\end{array}$ & & & & $139.35 * *$ & & & & $19.497 * *$ \\
\hline $\begin{array}{l}\text { Number of } \\
\text { observation } \\
\mathrm{S}\end{array}$ & 3097 & & & & 2511 & & & \\
\hline
\end{tabular}

Notes: Under the heading "demographics, policy, and financial development" the sample covers 143 countries with data available between 1980 and 2006. Under the heading "capital account openness and corruption," the sample covers 126 countries with data available between 1980 and 2006. The panel is unbalanced due to some missing observations. $* *$ and $*$ indicate $1 \%$ and $5 \%$ levels of significance, respectively. Heteroskedasticity-robust standard errors are given in parentheses underneath coefficient estimates. For the fixed effects models, the F-test statistics are reported for the null hypothesis of the equality of the constants across all countries in the sample. For the random effects models, the Hausman test statistics test for the independence between the time-invariant country-specific effects and the regressors. 


\section{Relative price level}

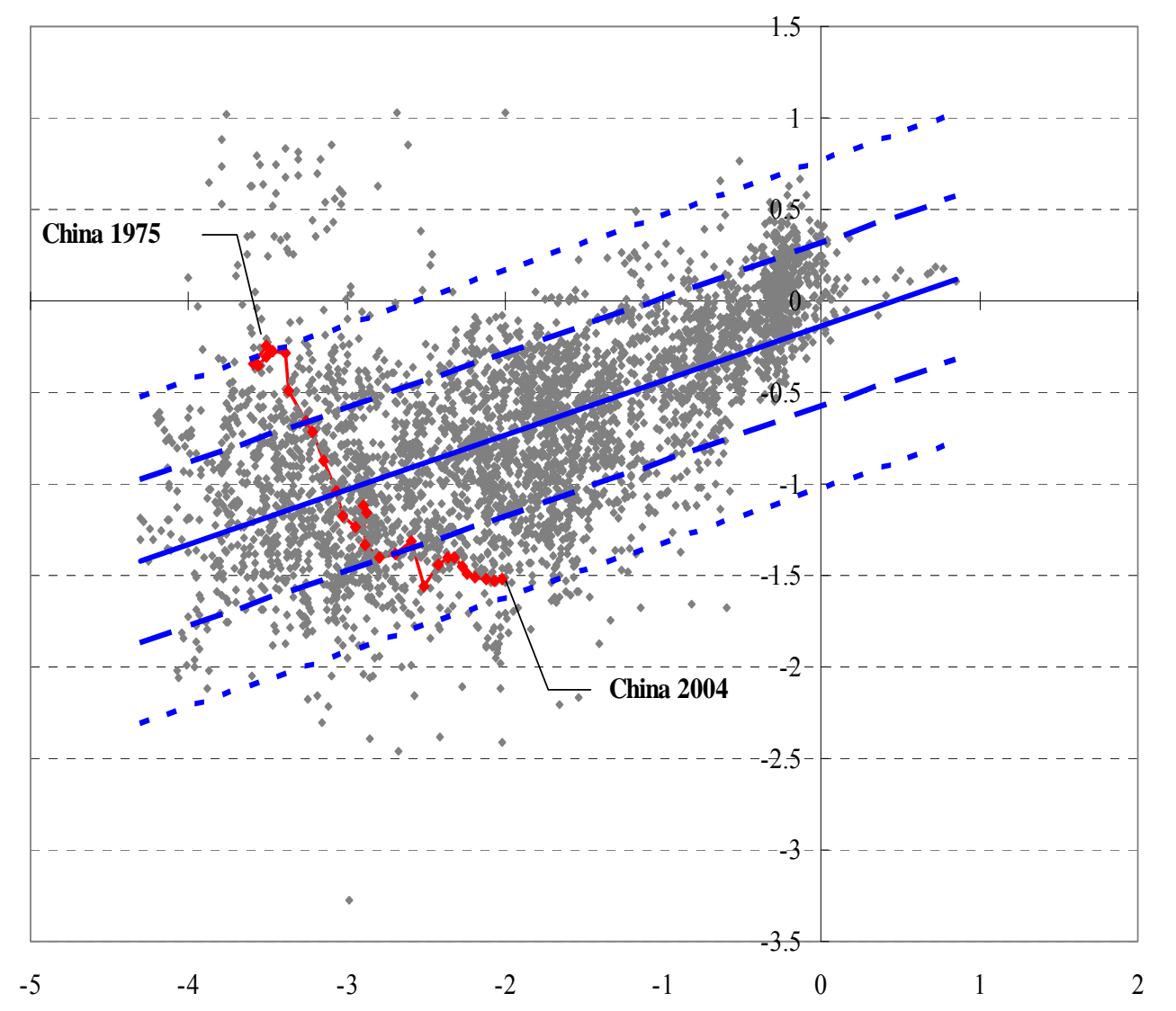

Relative per capita income in PPP terms

Figure 1: The rate of RMB misalignment based on the pooled OLS estimates with the PPPbased per capita income, 2006 vintage data 


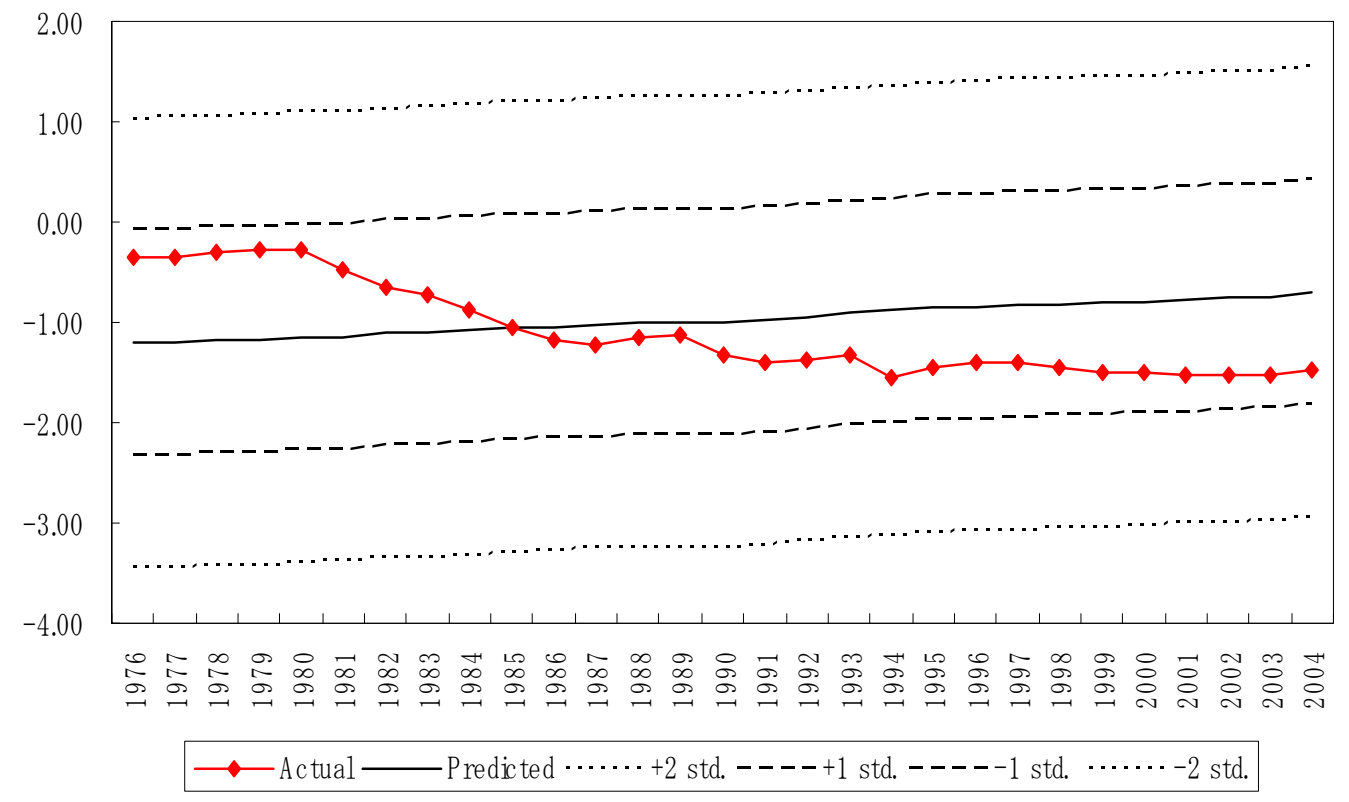

Figure 2: The actual and predicted RMB values by pooled OLS estimates with ad-hoc AR1 adjustment, 2006 vintage data

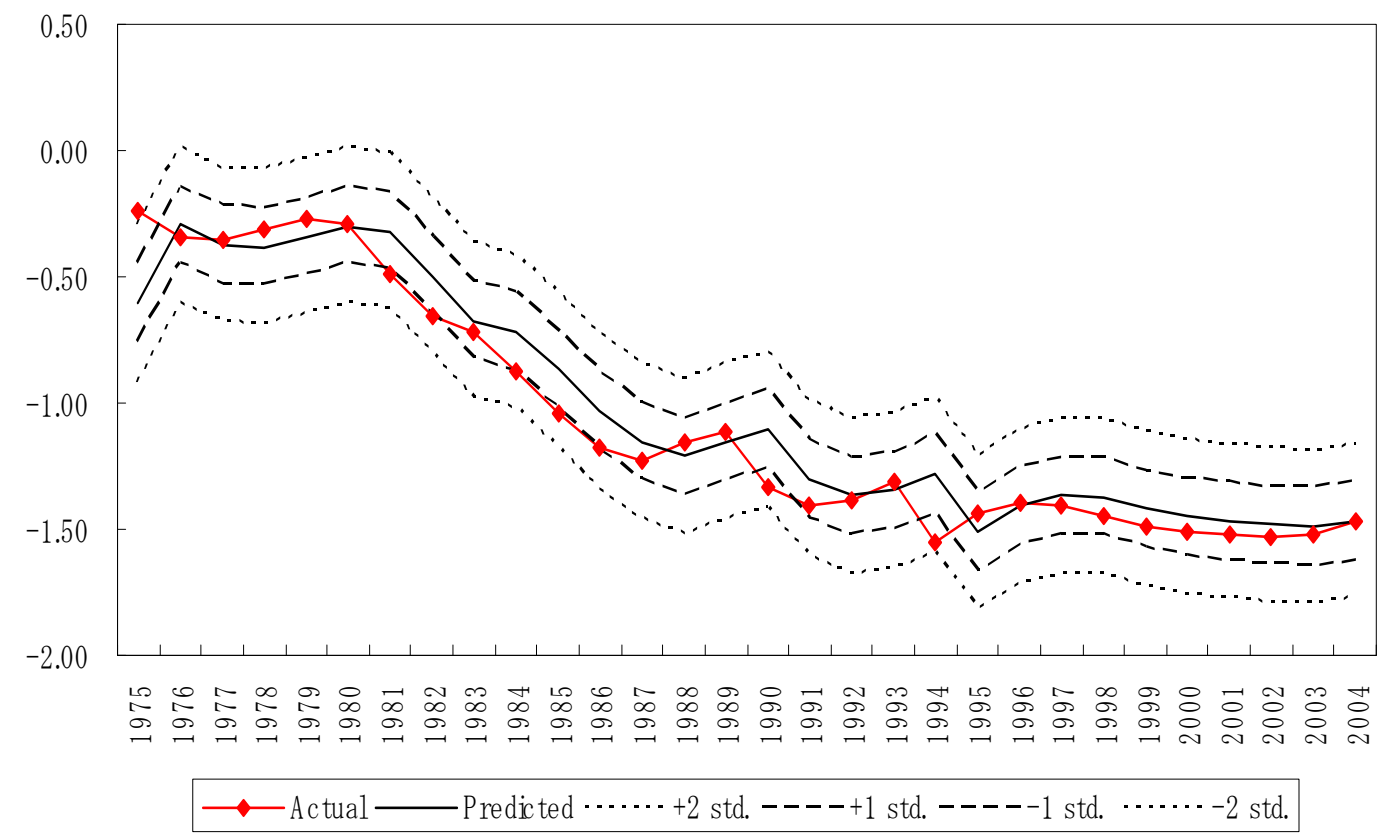

Figure 3: The actual and predicted RMB values by the Prais-Winsten estimates, 2006 vintage data 


\section{Relative price level}

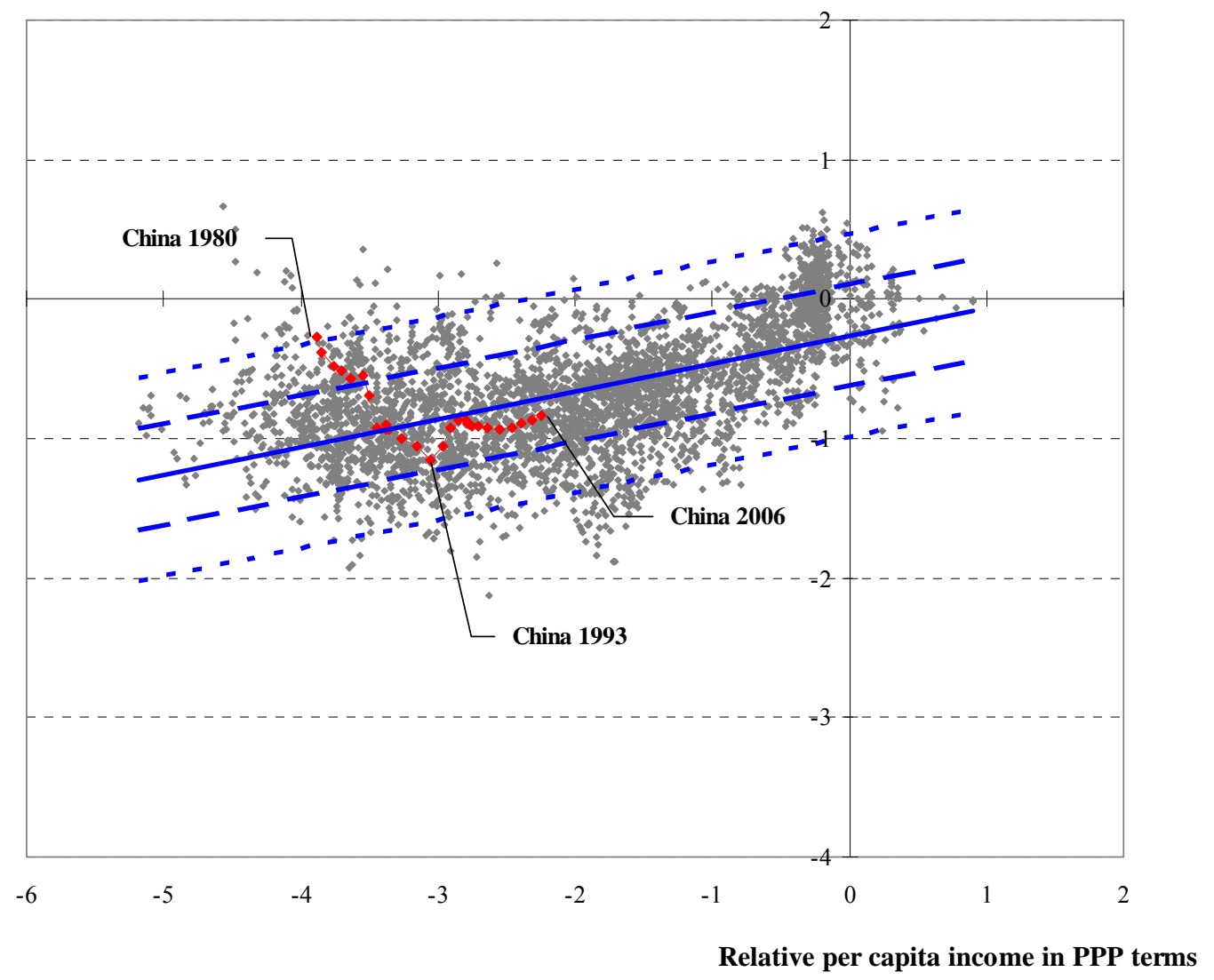

Figure 4 The rate of RMB misalignment based on the pooled OLS estimates with the PPP-based per capita income, 2008 vintage data 


\section{Relative price level}

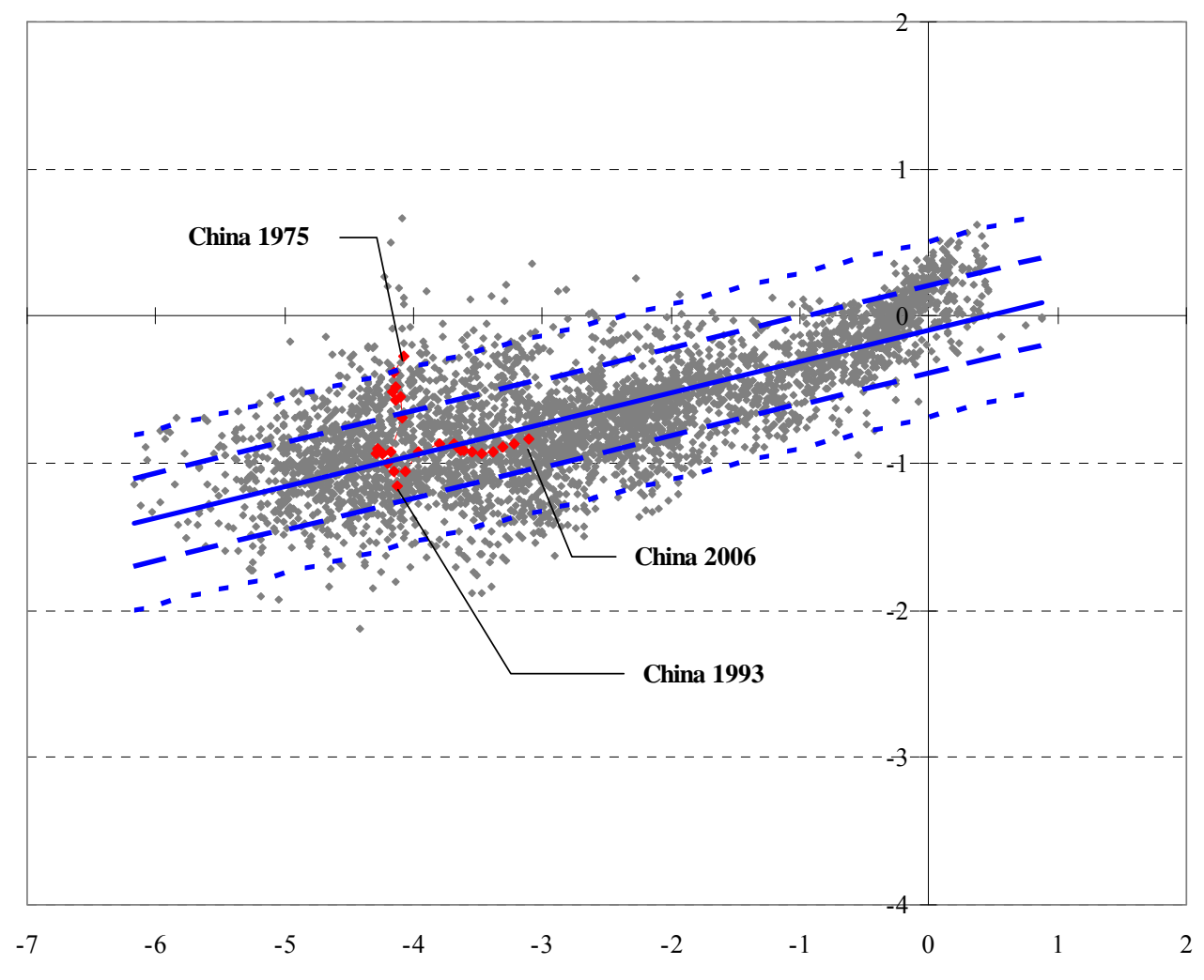

Relative per capita income in USD terms regression line - - 1 standard error

- - - . 2 standard error

Figure 5 The rate of RMB misalignment based on the pooled OLS estimates with the USDbased per capita income, 2008 vintage data 
RMB misalignment (PPP-based)

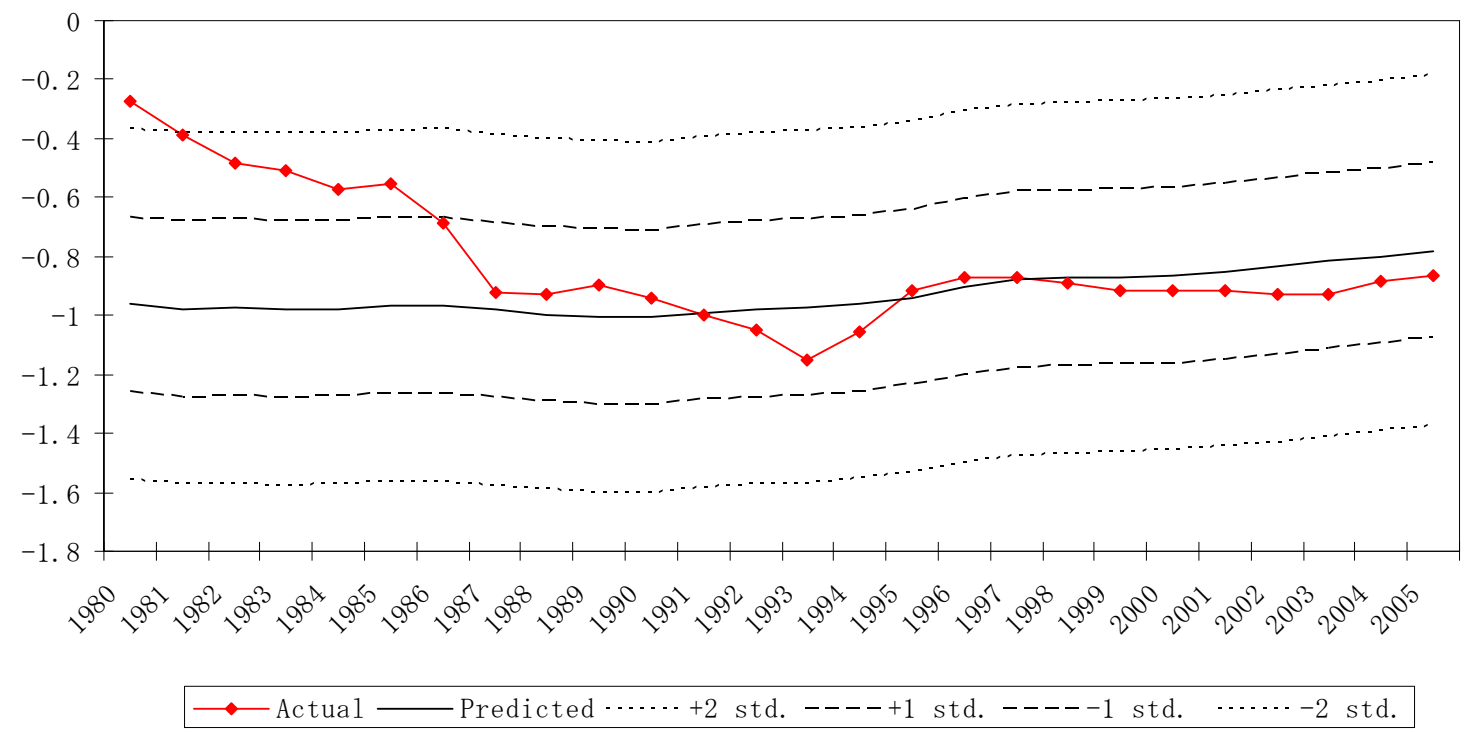

Figure 6: The actual and predicted RMB values by pooled OLS estimates on PPP GDP, 2008 vintage data

RMB misalignment (USD-based)

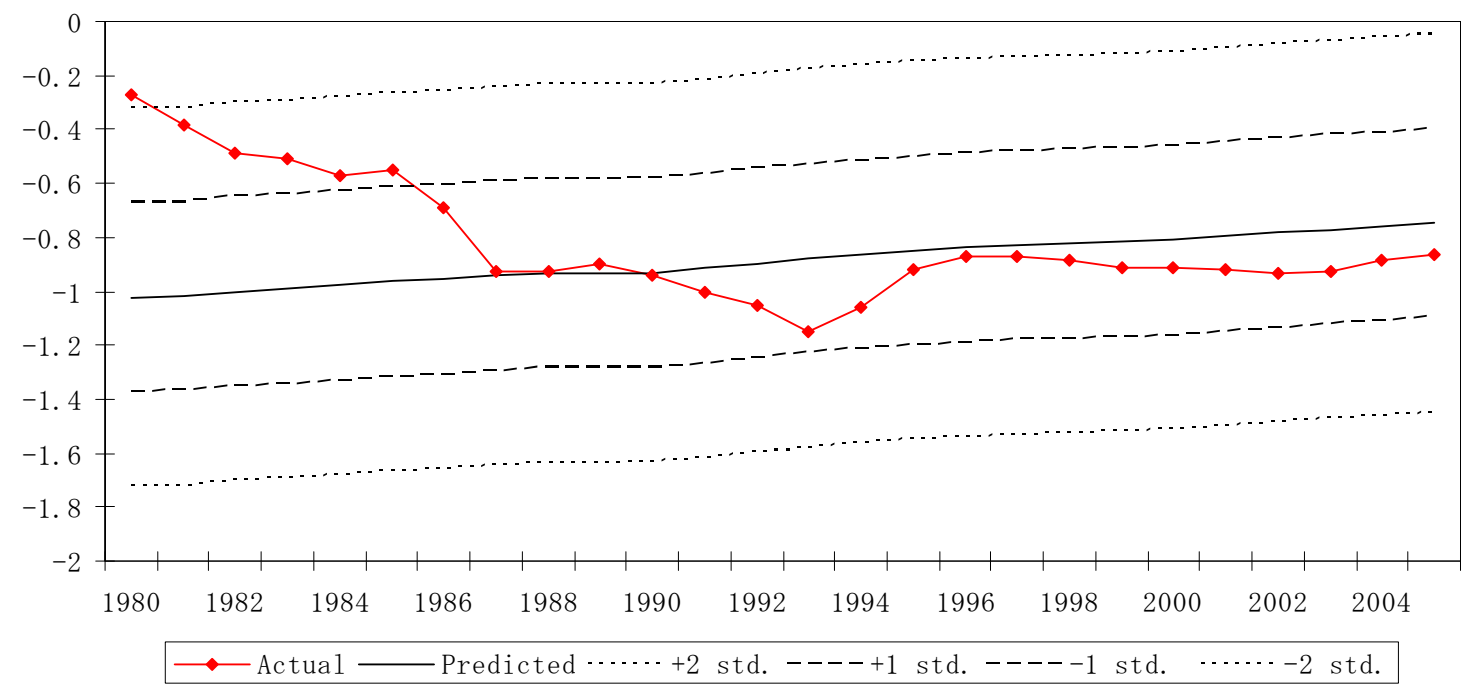

Figure 7: The actual and predicted RMB values by pooled OLS estimates on USD GDP, 2008 vintage data 